\title{
Protein $\mathrm{S}$ blocks the extrinsic apoptotic cascade in tissue plasminogen activator/N-methyl D-aspartate-treated neurons via Tyro3-Akt-FKHRL1 signaling pathway
}

Huang Guo ${ }^{1}$, Theresa M Barrett ${ }^{1}$, Zhihui Zhong ${ }^{1}$, José A Fernández², John H Griffin², Robert S Freeman², Berislav V Zlokovic $^{1^{*}}$

\begin{abstract}
Background: Thrombolytic therapy with tissue plasminogen activator (TPA) benefits patients with acute ischemic stroke. However, tPA increases the risk for intracerebral bleeding and enhances post-ischemic neuronal injury if administered 3-4 hours after stroke. Therefore, combination therapies with tPA and neuroprotective agents have been considered to increase tPA's therapeutic window and reduce toxicity. The anticoagulant factor protein $S$ (PS) protects neurons from hypoxic/ischemic injury. PS also inhibits N-methyl-D-aspartate (NMDA) excitotoxicity by phosphorylating Bad and Mdm2 which blocks the downstream steps in the intrinsic apoptotic cascade. To test whether PS can protect neurons from tPA toxicity we studied its effects on PAA/NMDA combined injury which in contrast to NMDA alone kills neurons by activating the extrinsic apoptotic pathway. Neither Bad nor Mdm2 which are PS's targets and control the intrinsic apoptotic pathway can influence the extrinsic cascade. Thus, based on published data one cannot predict whether PS can protect neurons from tPA/NMDA injury by blocking the extrinsic pathway. Neurons express all three TAM (Tyro3, Axl, Mer) receptors that can potentially interact with PS. Therefore, we studied whether PS can activate TAM receptors during a tPA/NMDA insult.

Results: We show that PS protects neurons from tPA/NMDA-induced apoptosis by suppressing Fas-ligand (FasL) production and FasL-dependent caspase-8 activation within the extrinsic apoptotic pathway. By transducing neurons with adenoviral vectors expressing the kinase-deficient Akt mutant Akt ${ }^{K 179 A}$ and a triple FKHRL1 Akt phosphorylation site mutant (FKHRL1-TM), we show that Akt activation and Akt-mediated phosphorylation of FKHRL1, a member of the Forkhead family of transcription factors, are critical for FasL down-regulation and caspase-8 inhibition. Using cultured neurons from Tyro3, Axl and Mer mutants, we show that Tyro3, but not Axl and Mer, mediates phosphorylation of FHKRL1 that is required for PS-mediated neuronal protection after TPA/ NMDA-induced injury.
\end{abstract}

Conclusions: PS blocks the extrinsic apoptotic cascade through a novel mechanism mediated by Tyro3-dependent FKHRL1 phosphorylation which inhibits FasL-dependent caspase-8 activation and can control tPA-induced neurotoxicity associated with pathologic activation of NMDA receptors. The present findings should encourage future studies in animal stroke models to determine whether PS can increase the therapeutic window of tPA by reducing its post-ischemic neuronal toxicity.

\footnotetext{
* Correspondence: berislav_zlokovic@urmc.rochester.edu

${ }^{1}$ Center for Neurodegenerative and Vascular Brain Disorders, Department of Neurosurgery and Neurology, University of Rochester Medical Center,

Rochester, NY 14642, USA

Full list of author information is available at the end of the article
} 


\section{Background}

Thrombolytic therapy for acute ischemic stroke with a recombinant tissue plasminogen activator (tPA) has clear benefits if administered within a relatively narrow therapeutic window [1-3]. However, studies using animal models of stroke have indicated that tPA may exert serious side effects in the ischemic brain which include bloodbrain barrier (BBB) breakdown [4-6] frequently resulting in intracerebral bleeding if systemic tPA is administered 3$4 \mathrm{~h}$ after stroke $[7,8]$. Moreover, a recent study using a model of angiographically documented recanalization of the rabbit middle cerebral artery occlusion has indicated that tPA produces bleeding at all doses in proportion to its thrombolytic potential [9]. These side effects limit use of tPA therapy in humans with stroke $[10,11]$.

Studies using a transient ischemia stroke models have demonstrated direct post-ischemic neuronal toxicity of tPA [12-14]. It has been also shown that tPA enhances neuronal injury in the presence of N-methyl-D-aspartate (NMDA) [15-18]. The exact mechanism(s) how tPA interacts with the NMDA receptors (NMDARs) has, however, been debated. Never-the-less most investigators agree that pathologic activation of NMDARs contributes to neuronal death after acute excitotoxic trauma such as brain ischemia $[19,20]$. It has been reported that tPA enhances the neurotoxic effects of NMDA downstream to NMDARs by shifting the NMDA-induced neuronal injury from the intrinsic to the extrinsic apoptotic pathway [14]. Therefore, potential combination therapies with tPA and neuroprotective agents hold potential to increase the therapeutic window of tPA and reduce its toxic effects in brain associated with pathologic activation of NMDARs.

Protein S (PS) is a vitamin K-dependent anticoagulant plasma glycoprotein with multiple biologic functions [21]. Independent of its anticoagulant activity, PS exerts direct cellular effects [22-24]. In the central nervous system, PS is neuroprotective after a transient brain ischemia and also protects cultured neurons from hypoxia/ glucose deprivation followed by reoxygenation [25]. PS enhances the $\mathrm{BBB}$ integrity after an ischemic insult as shown in a model of human BBB endothelial monolayers in vitro and after a transient ischemia in mice in vivo by acting on the TAM (Tyro3, Axl, Mer) receptor tyrosine kinase Tyro3 [26].

Recently, we have demonstrated that PS protects neurons from NMDA-induced excitotoxic injury by phosphorylating Bad and Mdm2 which in turn blocks the downstream steps in the intrinsic apoptotic cascade [27]. To test whether PS can protect neurons from tPA toxicity we employed a model of tPA and NMDA combined injury [14]. In contrast to NMDA alone, a simultaneous exposure of neurons to tPA and NMDA kills neurons by activating the extrinsic apoptotic pathway [14]. Bad [28,29] and Mdm2 [30,31] which control the intrinsic apoptotic cascade and p53/Bax proapoptotic pathway, respectively, are both targets of PS [27], but neither can influence the extrinsic cascade. Thus, based on the published work one cannot predict whether PS will protect neurons from tPA/NMDA injury by blocking the extrinsic pathway. Neurons express all three TAM receptors, i.e., Tyro3, Axl and Mer [32] Tyro3 and Mer were both shown to interact with PS on different cells types during physiologic and/ or pathologic conditions [33-35]. Moreover, triple TAM mutants develop neuronal apoptosis [36] and PS null mice develop neuronal necrosis [37,38]. All these studies suggest that interactions between different TAM receptors and PS might be important for neuronal survival. Therefore, we also studied whether PS can activate TAM receptors during a $\mathrm{TPA} / \mathrm{NMDA}$ insult.

\section{Results}

\section{PS protects mouse cortical neurons from tPA/NMDA-} mediated injury

Mouse recombinant PS dose-dependently enhanced cell survival (Figure 1A) and reduced by $>75 \%$ the number of TUNEL-positive cells (Figure 1B-C) in 14-day old cultures of mouse cortical neurons treated with tPA and NMDA, as described in the Methods and previously reported $[14,15]$. Because tPA/NMDA exposure has been shown to trigger caspase-8-dependent cell death [14], we explored whether PS attenuates tPA/NMDAinduced toxicity by blocking the extrinsic apoptotic pathway. Initial experiments showed that treatment with caspase- 8 and caspase- 3 inhibitors (z-IETD-fmk, AcDEVD-CHO), but not caspase-9 inhibitor (z-LEHDfmk), enhanced cell survival (Figure 1D), confirming that $\mathrm{PA} / \mathrm{NMDA}$-induced neuronal cell death is caspase8 -dependent and that caspase- 8 is upstream to caspase3 , as reported [14]. Consistent with these results, activation of both caspase- 8 and caspase- 3 in tPA/ NMDA-treated neurons was suppressed by the caspase8 inhibitor z-IETD-fmk, but not by a caspase- 9 inhibitor (Figure 1E-F). Treatment with PS (100 nM) blocked the tPA/NMDA-mediated activation of both caspase- 8 and caspase-3. In these studies PS was added at concentration of $100 \mathrm{nM}$ because the maximal protection with murine PS in the present model has been achieved with $100 \mathrm{nM}$ (Figure 1A).

In the extrinsic cell death pathway, activation of caspase- 8 is coupled to activation of death receptors by proteins such as FasL [39]. Indeed, tPA/NMDA treatment increased FasL expression (Figure 1G). Moreover, addition of an anti-FasL neutralizing antibody at the time of tPA/NMDA exposure prevented activation of caspase- 8 (Figure $1 \mathrm{H}$ ). tPA/NMDA exposure failed to elicit an increase in FasL expression in cells treated with 

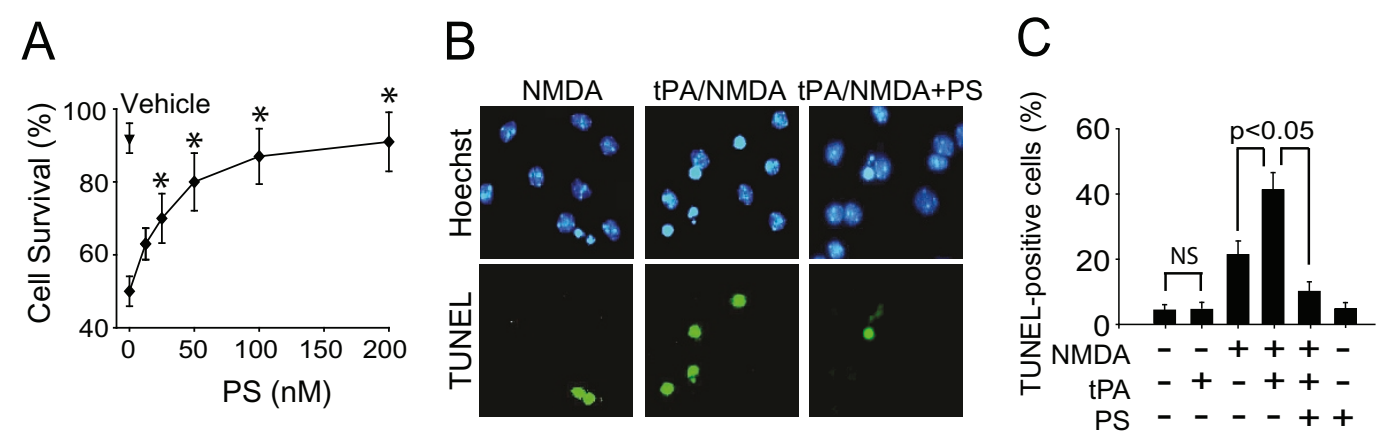

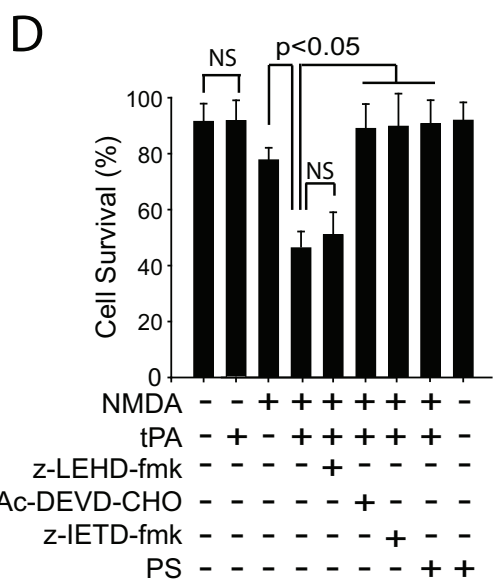

E

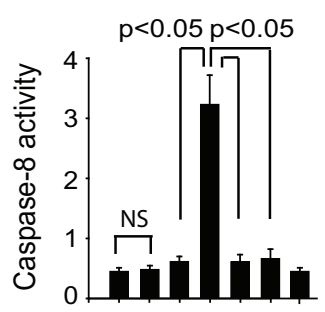

NMDA --++++-

tPA -+-+++

z-IETD-fmk - - - + - -

PS - - - - + +
F

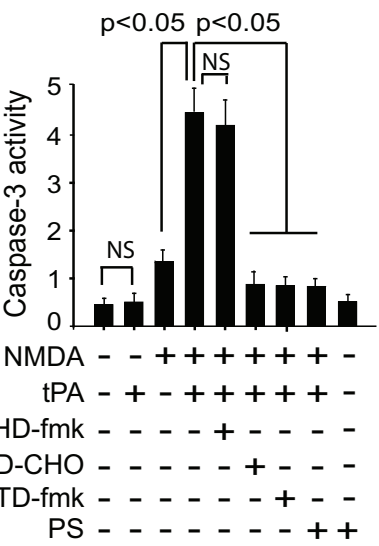

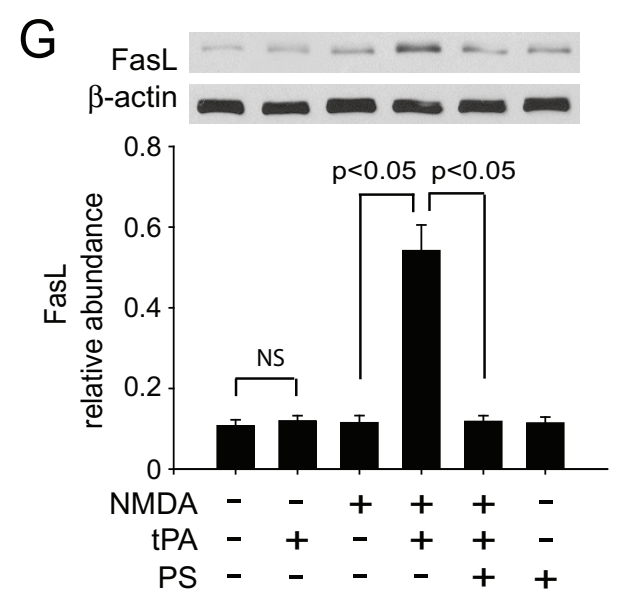

H

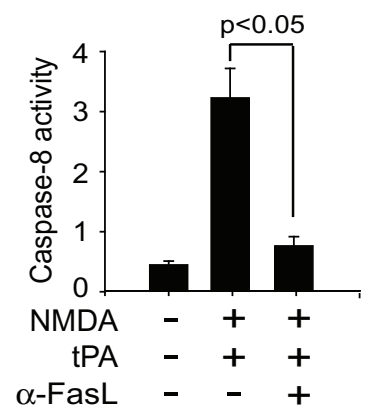

Figure 1 PS protects mouse cortical neurons from tPA/NMDA-induced injury. (A) Dose-dependent neuroprotective effects of PS (12.5-200 $\mathrm{nM}$ ) in a 14-day old neuronal cultures $24 \mathrm{~h}$ after tPA/NMDA treatment. Cell survival was quantified with a WST assay. (B) Representative fluorescent-TUNEL (green)/Hoechst (blue) staining in mouse cortical neurons $24 \mathrm{~h}$ after tPA/NMDA treatment in the presence or absence of PS. (C) The number of apoptotic TUNEL-positive cells quantified as described in the Methods in the presence of NMDA with and without tPA or PS. (D) Survival of mouse cortical neurons $24 \mathrm{~h}$ after a combined tPA/NMDA treatment with and without PS, caspase-9 inhibitor ( $\mathrm{z}$-LEHD-fmk 5 HM), caspase-8 inhibitor (z-IETD-fmk, $50 \mu \mathrm{M}$ ), or caspase-3 inhibitor (Ac-DEVD-CHO, $50 \mu \mathrm{M}$ ). (E) Caspase-8 activity in mouse cortical neurons 8 h after tPA/NMDA exposure in the presence or absence of PS and a caspase-8 inhibitor (z-IETD-fmk; $50 \mu M$ ). (F) Caspase-3 activity in mouse cortical neurons $12 \mathrm{~h}$ after tPA/NMDA in the presence or absence of PS, caspase-9 inhibitor (z-LEHD-fmk $5 \mu M$ ), caspase-8 inhibitor ( $z$-IETD-fmk, 50 HM), or caspase-3 inhibitor (Ac-DEVD-CHO, $50 \mu \mathrm{M}$ ). (G) Western blots for FasL in whole-cell extracts from mouse cortical neurons 6 h after tPA/NMDA in the presence or absence of PS. Intensity of FasL signal was measured by scanning densitometry and normalized to $\beta$-actin. (H) Caspase-8 activity in mouse cortical neurons $8 \mathrm{~h}$ after tPA/NMDA in the presence of anti-FasL antibody ( $\alpha$-FasL; $10 \mu \mathrm{g} / \mathrm{ml})$. Anti-FasL antibody was added simultaneously with tPA-NMDA. Caspase inhibitors were applied $1 \mathrm{~h}$ prior to tPA/NMDA treatment. In all studies murine PS was used at 100 nM, unless specified differently, and was added simultaneously with tPA (20 $\mu \mathrm{g} / \mathrm{ml})$ and NMDA $(25 \mu \mathrm{M})$. Mean \pm SEM, $\mathrm{n}=3$ independent cultures in triplicate. ${ }^{*} \mathrm{p}<0.05$ compared with values in the absence of PS. NS, non-significant. 
PS (Figure 1G) suggesting that this may be the mechanism by which PS prevents caspase- 8 activation. Treatment with tPA alone and PS alone did not affect the number of TUNEL-positive cells, cell survival, caspase- 8 and caspase- 3 activities, and FasL production (Figure $1 \mathrm{C}-\mathrm{G})$. In this model, treatment with NMDA alone caused less severe neuronal injury compared to tPA/ NMDA combination (Figure 1C-D) and did not affect caspase- 8 activity (Figure $1 \mathrm{E}$ ), consistent with a previous report [14].

\section{PS neuroprotection requires activation of Akt signaling}

PS requires activation of the phosphatidylinositol 3-kinase (PI3K)/Akt survival pathway as an upstream signaling event to prevent NMDA-mediated neuronal injury [27]. Thus, we tested whether the ability of PS to protect neurons from tPA/NMDA-mediated injury also requires $\mathrm{PI} 3 \mathrm{~K} / \mathrm{Akt}$ activation as an initial step mediating the observed neuronal protection. PS treatment stimulated phosphorylation of Akt on Ser473 [40] in neurons after tPA/NMDA challenge (Figure 2A-B). Because phosphorylation levels of Akt may not entirely reflect its protein kinase activity, we performed an immune complex kinase assay using glycogen synthase kinase 3 (GSK3) as the Akt substrate [41]. Results from these experiments confirmed that PS treatment stimulates Akt kinase activity (Figure 2C-D). LY294002, a PI3K inhibitor, blocked PS-mediated phosphorylation of Akt (Figure $2 \mathrm{~A}-\mathrm{B}$ ) and neuronal protection (Figure 2E) after tPA/ NMDA exposure. This data suggests that PS's neuroprotective effects requires an initial activation of the PI3K/ Akt pathway.

Activated Akt promotes cell survival in the extrinsic apoptotic pathway by phosphorylating and inactivating

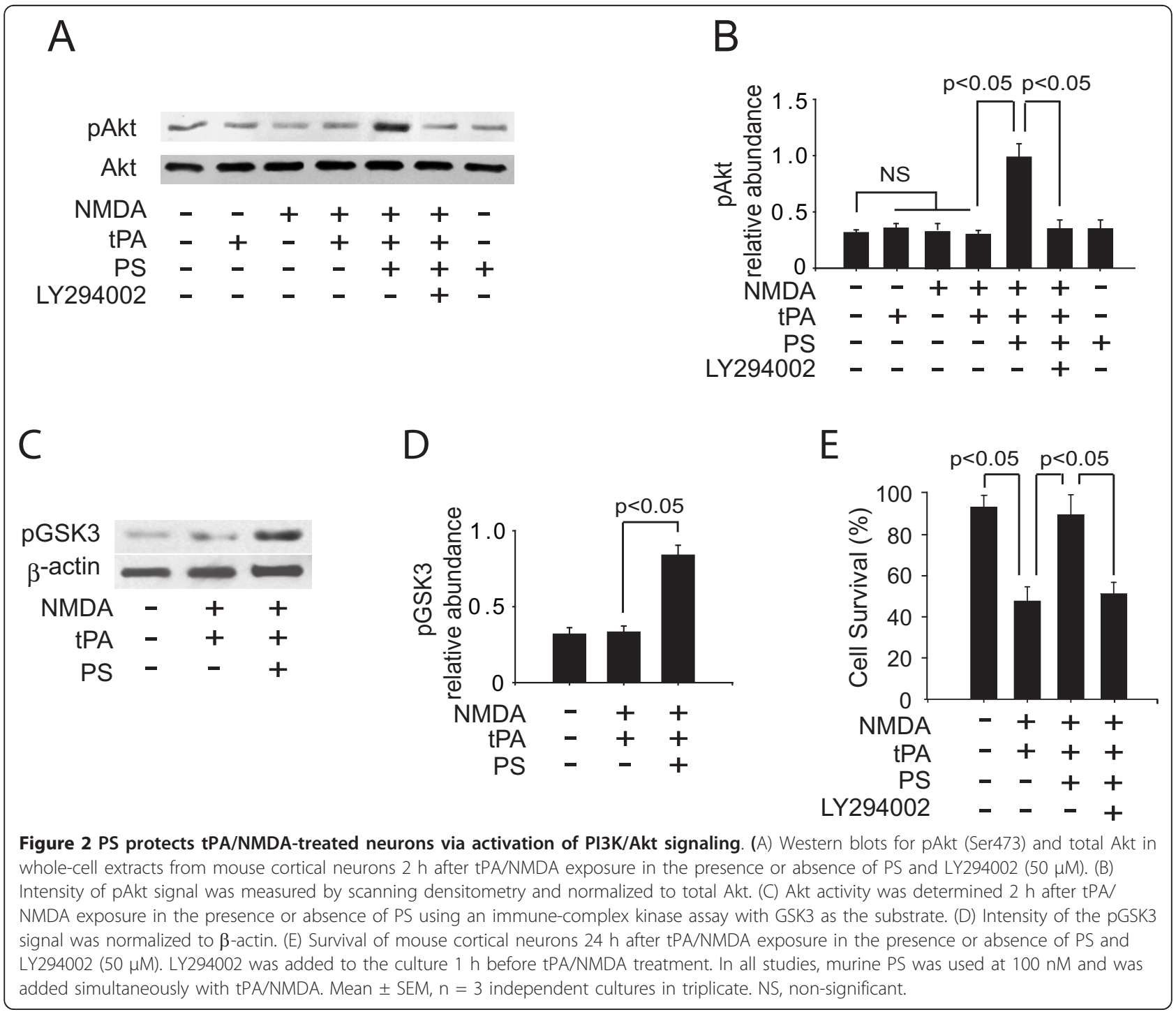


FKHRL1, a member of the Forkhead family of transcription factors [42]. Phosphorylation of FKHRL1 results in its cytoplasmic retention, whereas dephosphorylated FKHRL1 translocates into the nucleus where it stimulates transcription of its target genes including FasL in the extrinsic apoptotic pathway $[40,42]$. Thus, we determined the protein levels of three members of the Forkhead family, FKHRL1, FKHR and AFX [43-45] in nuclear fractions prepared from tPA/NMDA-treated neurons. Nuclear levels of FKHRL1, but not of FKHR and AFX1, were significantly increased by tPA/NMDA challenge (Figure 3A-B). PS treatment blocked the increase in nuclear FKHRL1 (Figure 3A-B), and this was accompanied by an increase in the amount of FKHRL1 phosphorylated on Ser253 (a site phosphorylated by Akt [42]) in whole cell lysates from
tPA/NMDA-treated neurons (Figure 3C). However, PS did not affect the levels of nuclear FKHRL1 and phosphorylated FKHRL1 in neurons without TPA/NMDA challenge (Figure 3A, C).

To confirm whether Akt plays a key role in PSmediated neuronal protection, mouse cortical neurons were transduced with a recombinant adenovirus expressing a kinase-deficient Akt mutant (Ad. $A k t^{K 179 A}$ ) [46] along with GFP. The transduction efficiency was $\sim 70 \%$ as determined by GFP fluorescence (data not shown). Figure 3D shows that mouse cortical neurons transduced with Ad. $A k t^{K 179 A}$ did not affect cell survival within $48 \mathrm{~h}$ of transduction. Ad. $A k t^{K 179 A}$ expression, but not control Ad.GFP, abolished PS-stimulated phosphorylation of FKHRL1 (Figure 3E), down-regulation of FasL (Figure 3F), inhibition of caspase-8 (Figure 3G) and

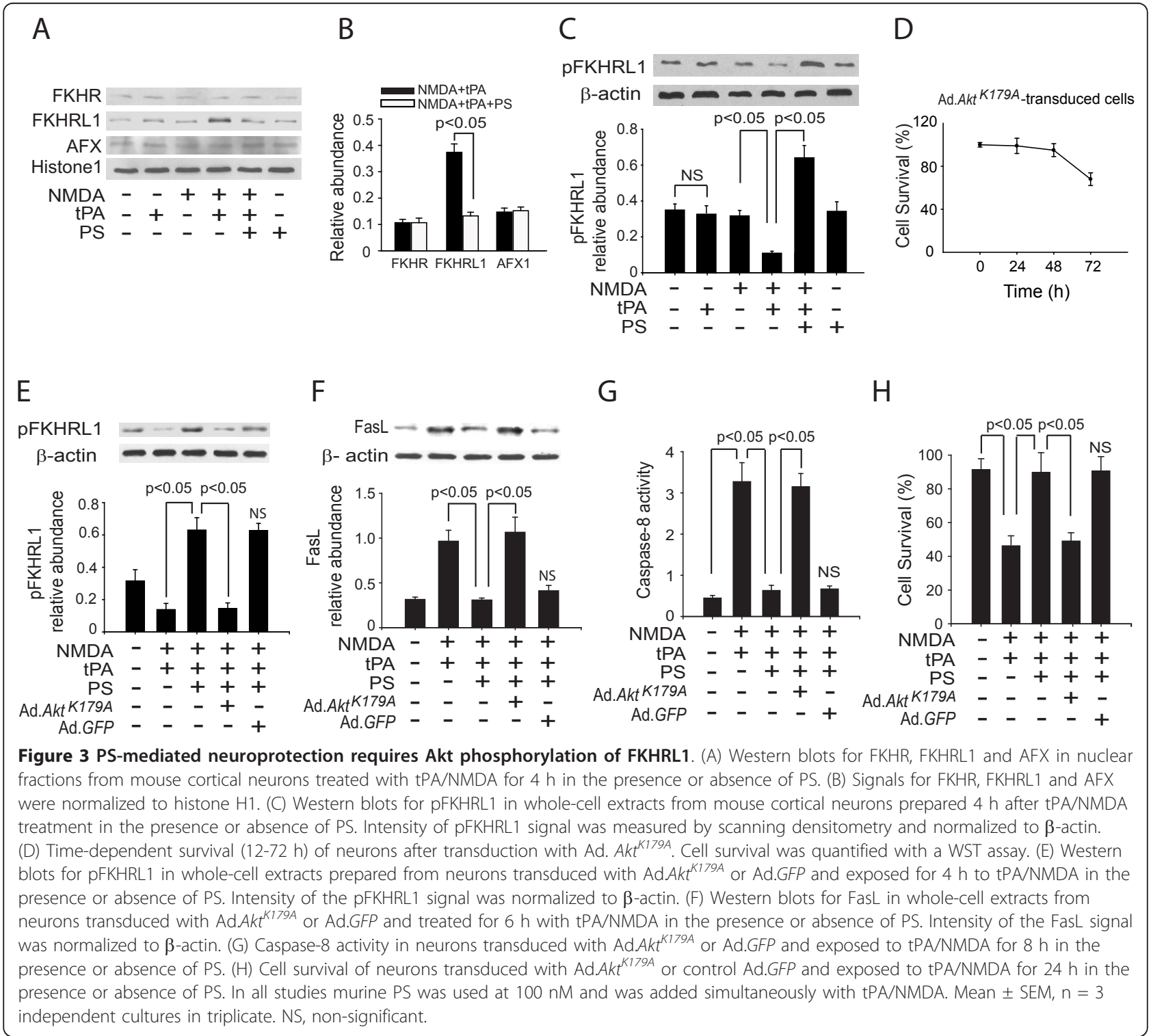


neuronal protection (Figure $3 \mathrm{H}$ ) in neurons exposed to tPA/NMDA.

We then tested the importance of phosphorylation of FKHRL1 in PS-mediated neuronal protection. Mouse cortical neurons were transduced with recombinant adenovirus expressing a triple mutant of FKHRL1 (Ad. FKHRL1-TM), which cannot be phosphorylated by Akt [47]. The transduction efficiency was $\sim 70 \%$ as assessed by GFP fluorescence (data not shown). Figure 4A illustrates the level of expression of FKHRL1-TM in mouse cortical neurons compared to endogenous FKHRL1 in control neurons. Since neurons expressing FKHRL1-TM may undergo apoptosis [48], we examined the viability of neurons transduced with Ad.FKHRL1-TM. Our data showed that mouse cortical neurons transduced with Ad.FKHRL1-TM did not undergo spontaneous apoptosis within $48 \mathrm{~h}$ of transduction, although they did show about 35\% decrease in survival at $72 \mathrm{~h}$ (Figure 4B). Thus, in subsequent experiments we transduced neurons with Ad.FKHRL1-TM 24 h before tPA/NMDA treatment. Results from these experiments showed that Ad.FKHRL1-TM expression abolishes PS-mediated down-regulation of FasL (Figure 4C), inhibition of caspase-8 (Figure 4D) and neuronal protection (Figure 4E), suggesting that FKHRL1 is a critical downstream step in the PS-mediated blockade of the extrinsic apoptotic pathway.

\section{Tyro3 mediates PS neuroprotection and FKHRL1 phosphorylation}

Next, we tested the role of TAM receptors in PS protection of tPA/NMDA-treated neurons. Using cortical neurons from $\mathrm{Tyro3}^{-/-}, \mathrm{Axl}^{-/-}$and $\mathrm{Mer}^{-/-}$mice, we found that PS protects neurons lacking Axl and Mer from tPA/NMDA-mediated injury, but failed to protect neurons lacking Tyro3 (Figure 5A). Consistent with a model whereby PS acts through Tyro3, we found that mouse PS stimulated tyrosine phosphorylation of Tyro3 on mouse cortical neurons challenged by tPA and NMDA (Figure 5B). However, PS failed to

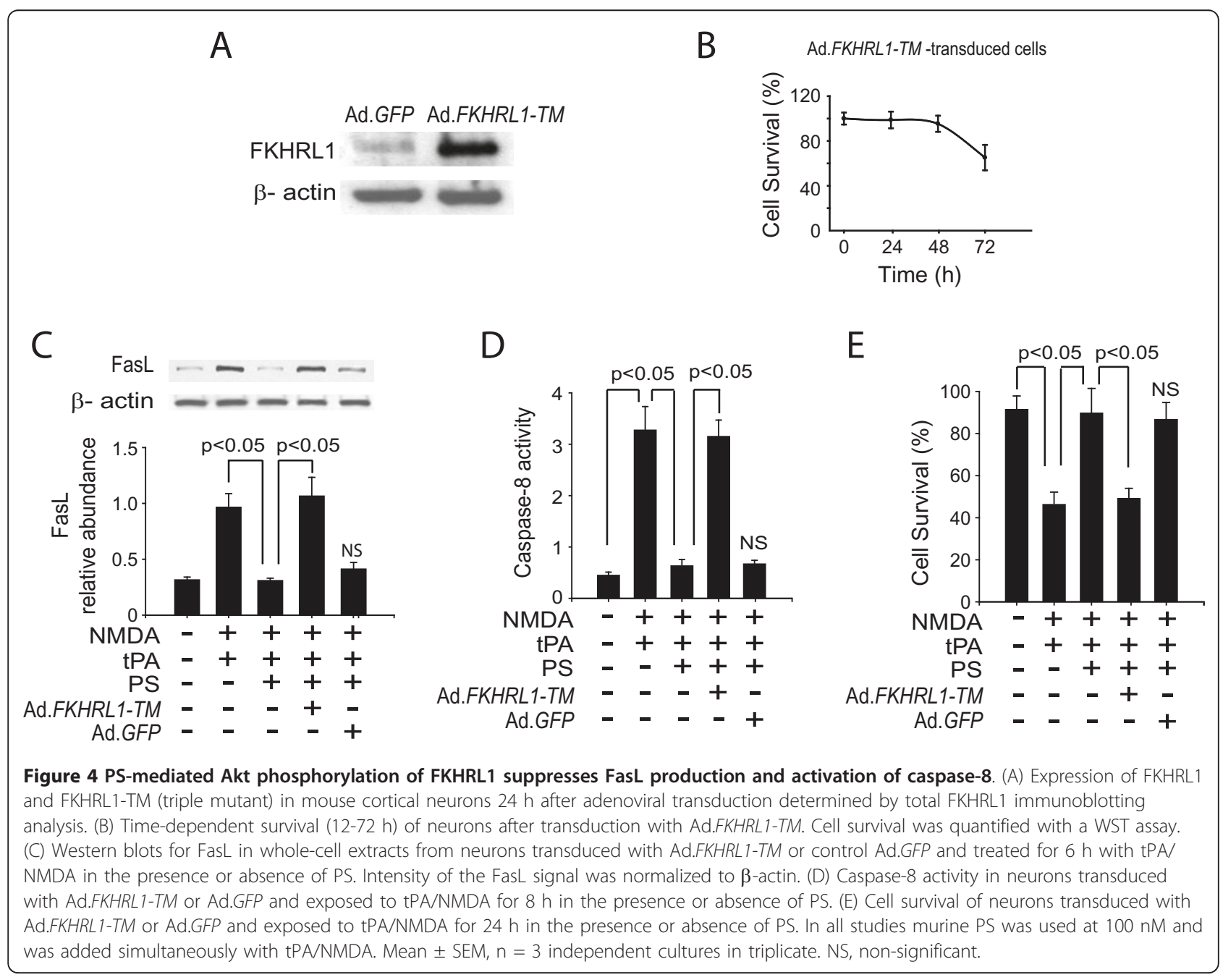




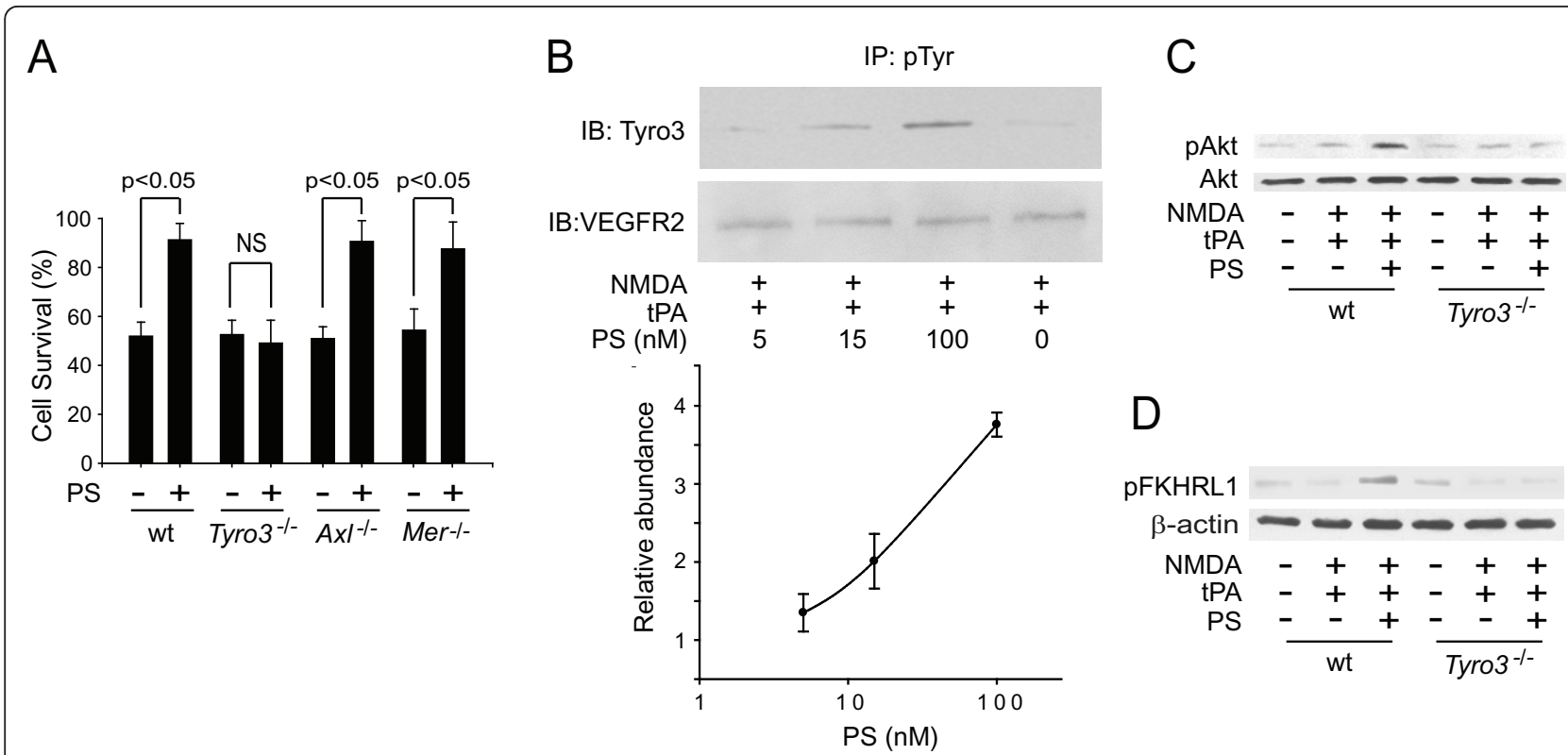

Figure 5 PS neuroprotection requires Tyro3 activation. (A) Cell survival of cortical neurons isolated from Tyro3, Axl or Mer null mice and wild type (wt) mice after $24 \mathrm{~h}$ of tPA/NMDA exposure in the presence or absence of PS. Cell survival was quantified with a WST-8 assay. (B) PS dosedependently mediates Tyro3 tyrosine phosphorylation in tPA/NMDA-treated mouse cortical neurons as determined by immunoprecipitation (IP) with anti-phospho-tyrosine (pTyr) antibody followed by immunoblotting (IB) with anti-Tyro3 antibody and anti-VEGFR2 (vascular endothelial growth factor receptor 2) antibody (as a loading control) $2 \mathrm{~h}$ after TPA/NMDA. Graph, relative abundance of phosphorylated Tyro3 to VEGFR2. (C) Akt phosphorylation (pAkt, Ser473) in neurons isolated from Tyro3 null mice and wt controls exposed to tPA/NMDA for $2 \mathrm{~h}$ in the presence or absence of PS. (D) FKHRL1 phosphorylation (pFKHRL1, Ser253) in neurons isolated from Tyro3 null mice and wt controls exposed to tPA/ NMDA for $4 \mathrm{~h}$ in the presence or absence of PS. In all studies murine PS was used at $100 \mathrm{nM}$ unless specified and was added simultaneously with $\mathrm{tPA} / \mathrm{NMDA}$. Mean $\pm \mathrm{SEM}, \mathrm{n}=3$ independent cultures in triplicate. NS, non-significant.

activate Akt (Figure 5C) and phosphorylate FKHRL1 (Figure 5D) in tPA/NMDA-treated neurons from Tyro3 null mice.

\section{Discussion}

It has been recently reported that PS phosphorylates the TAM receptor Tyro3 in neurons which protects NMDA-treated neurons from cell death by inhibiting the intrinsic apoptotic cascade [27]. Specifically, it has been shown that PS acts on Tyro3 which activates the PI3K/Akt pathway in NMDA-treated neurons resulting in phosphorylation of Bad and $\mathrm{Mdm} 2$ which in turn increases the levels of antiapoptotic Bcl-2 and Bcl- $\mathrm{X}_{\mathrm{L}}$ proteins and reduces the levels of proapoptotic p53 and Bax, respectively, thus inhibiting the intrinsic apoptotic cascade initiated by NMDA [27]. However, in the present model of a combined tPA/NMDA injury, a simultaneous exposure to tPA and NMDA activates the extrinsic apoptotic cascade but does not affect or amplify the intrinsic apoptotic pathway, as we reported [14]. Moreover, the established phosphorylation targets of PS in the intrinsic apoptotic cascade, i.e., Bad [28,29] and Mdm2 [30,31] as shown by a previous study [27], do not influence the extrinsic cascade.
The present study shows for the first time that PS can block the extrinsic apoptotic cascade and protect neurons from a combined tPA/NMDA-mediated injury. We also show that inhibition of the extrinsic apoptotic cascade by PS requires Tyro3-mediated phosphorylation of FKHRL1 which in turn inhibits FasL production and FasL-dependent caspase- 8 activation in the extrinsic pathway. These results suggest that PS may protect neurons from divergent inducers of apoptosis acting through either intrinsic or extrinsic pathways, similar as reported for activated protein C [49]. By using Tyro3-, Axl- and Mer-deficient neurons, the present study demonstrates that an initial upstream event in PS-mediated protection against tPA/ NMDA combined injury requires Tyro3 and activation of the PI3K/Akt anti-apoptotic signaling pathway as in an NMDA alone-mediated neuronal injury [27]. However, the present study in tPA/NMDA-treated neurons establishes the link between PS-mediated activation of Tyro3 and FKHRL1 phosphorylation which inactivates proapoptotic FKHRL1 [42] and mediates PS's beneficial effects. Namely, dephosphorylated FKHRL1 can trigger the extrinsic apoptotic cell death by promoting expression of FasL followed by FasL-dependent activation of caspase-8 $[40,42]$. Our data using a triple Akt-phosphorylation site mutant of FKHRL1 (i.e., FKHRL1-TM) [47] 
indicate that FKHRL1 is a critical target of Akt after neuronal injury involving activation of the extrinsic cascade. Moreover, our data shows that PS-mediated inactivation of FKHRL1 suppresses tPA/NMDA-induced FasL upregulation which subsequently blocks caspase- 8 activation.

The importance of the extrinsic apoptotic cascade for tPA/NMDA-mediated toxicity is further supported by observation that $>80 \%$ of caspase- 3 activation in tPA/ NMDA-treated neurons was blocked by a caspase- 8 inhibitor, but not with a caspase- 9 inhibitor, similar as shown in a previous study [14]. Both pro-caspase- 3 and Bid, a proapoptotic promoter of cytochrome c release [50], are substrates for caspase-8. However, it has been shown that TPA/NMDA-induced apoptotic signaling does not require amplification through the intrinsic pathway via Bid [14] in contrast to ischemic neuronal death in vivo [50,51]. Therefore, our results are consistent with a model in which PS blocks FasL and FasLdependent activation of caspase- 8 followed by inhibition of caspase- 3 activation resulting in protection of tPA/ NMDA-treated neurons.

In addition to the effects of a combined tPA/NMDA injury on signaling pathways downstream to NMDARs, as shown in the present and a previous study [14], it has been also suggested that TPA may interact directly with NMDARs. For example, it has been proposed that tPA cleaves the NR1 subunit of NMDARs potentiating NMDA-induced calcium influx and neurotoxicity $[15,17,52]$ or that NR2D-containing NMDARs mediate tPA-induced neuronal excitotoxicity [16], but this has not been confirmed by other groups [18]. It has been reported that seizures induced by ethanol-withdrawal are controlled by tPA through modulation of NR2Bcontaining NMDARs [53]. Other studies have indicated that IPA binding to the low-density lipoprotein receptor related protein-1 (LRP1) is necessary for NMDARs activation [54] and upregulation of matrix metalloproteinase-9 expression at the $\mathrm{BBB}$ [55] resulting in an increased BBB permeability $[4,56]$ which in turn may lead to accumulation in brain of blood-derived neurotoxins and vascular-mediated neuronal injury [57], as shown for example in pericyte-deficient mouse models $[58,59]$. Whether PS can act directly on NMDARs or LRP1 to attenuate the neurotoxic signaling during a tPA/NMDA-mediated insult should be addressed by the future studies.

\section{Conclusions}

Our data suggests that PS blocks the extrinsic apoptotic cascade through Tyro3-dependent phosphorylation of FKHRL1 which in turn inhibits FasL-dependent caspase-8 activation and controls tPA-induced neuronal toxicity associated with pathologic activation of NMDA receptors.
These findings should encourage future preclinical studies in different animal stroke models using different species and different administration regimens of tPA and PS to determine whether PS can increase the therapeutic window of tPA by reducing its risk for intracerebral bleeding and/or post-ischemic neuronal toxicity.

\section{Methods \\ Reagents}

Full-length properly gamma-carboxylated mouse recombinant PS was prepared and characterized as we reported [23]. NMDA was purchased from Sigma (St Louis, MO, USA). Mouse recombinant tPA was purchased from Molecular Innovations (Novi, MI, USA). For western blot analysis the following antibodies were used: polyclonal rabbit antibody against mouse Fas Ligand (FasL; EMD4Biosciences, Gibbstown, NY, USA), polyclonal rabbit antibody against mouse Akt (Cell Signaling, Danvers, MA, USA), polyclonal rabbit antibody against mouse pAkt (Cell Signaling), polyclonal rabbit antibody against human FKHR which cross reacts with mouse FKHR (Cell Signaling), polyclonal rabbit antibody against human FoxO3a which cross reacts with mouse FoxO3a (FKHRL1, Cell Signaling), polyclonal rabbit antibody against human pFoxO3a which cross reacts with mouse pFoxO3a (pFKHRL1, Cell Signaling), polyclonal rabbit antibody against human AFX which cross reacts with mouse AFX (Cell Signaling), and polyclonal sheep antibody against human histone 1 , which cross reacts with mouse histone 1 (United States Biological, Swampscott, MA, USA). The inhibitory peptides, AcDEVD-CHO (caspase-3), z-IETD-fmk (caspase-8) and zLEHD-fmk (caspase-9) were selected on the basis of substrate specificity [14] and purchased from Sigma. LY294002 was purchased from Cell Signaling. Anti-FasL neutralizing antibody was selected as reported $[60,61]$ and purchased from BD Pharmingen (clone MFL3; San Diego, CA, USA).

\section{Transgenic mice}

TAM transgenic mice $\left(\right.$ Tyro3 $\left.^{-/}, \mathrm{Axl}^{-/}, \mathrm{Mer}^{-1}\right)$ were originally on C57B16/129 background [62,36]. These mice were backcrossed for 10 generations to attain the C57B16 background and were generated by null-null breeding. The C57B16 mice were used as wild type controls for the TAM null mice, as reported [[63]; please see also the Jackson Laboratory website http://jaxmice. jax.org/strain/007937.html]. The breeding pairs were originally provided by Dr. G. Lemke from the Salk Institute for Biological Studies, La Jolla, CA.

\section{Mouse neuronal cell cultures}

Primary neuronal cultures were established as described [49]. In brief, cerebral cortex was dissected from 
embryonic day 16 from C57BL/6J mice and different TAM null mice, treated with trypsin for $10 \mathrm{~min}$ at $37^{\circ} \mathrm{C}$ and dissociated by trituration. Dissociated cell suspensions were plated at $3.5 \times 10^{5}$ cells per well on 12-well tissue culture plates or at $1.5 \times 10^{6}$ cells per well on 6well tissue culture plates coated with poly-L-lysine, in serum-free Neurobasal medium plus B27 supplement (Gibco, Rockville, MA, USA). The medium suppresses glial growth to $<0.5 \%$ of the total cell population, as demonstrated by immunocytochemistry for glial fibrilary acidic protein $[64,65]$. Cultures were allowed to mature for 14 days in vitro before treatment as reported [14]. Medium was replaced every 3 days.

\section{tPA/NMDA injury model}

For induction of neuronal apoptosis, neuronal cultures were treated with mouse recombinant tPA $(20 \mu \mathrm{g} / \mathrm{ml})$ and $25 \mu \mathrm{M} \mathrm{NMDA} / 5 \mu \mathrm{M}$ glycine in serum-free Neurobasal medium plus B27 supplement for 2-24 h as reported $[14,15]$.

\section{Detection of apoptosis}

Apoptotic cells were visualized by in situ terminal deoxynucleotidyl transferase-mediated digoxigenin-dUTP nick-end labeling (TUNEL) assay according to manufacturer's instructions (Promega, Madison, WI, USA). Cells were counterstained with the DNA-binding fluorescent dye, Hoechst 33342 (Molecular Probes, Eugene, OR, USA) at $1 \mu \mathrm{g} / \mathrm{ml}$ for $10 \mathrm{~min}$ at room temperature to reveal nuclear morphology. Images were obtained using a Zeiss 510 meta confocal microscope. The number of apoptotic cells was expressed as the percentage of TUNEL-positive cells of the total number of nuclei determined by Hoechst staining.

\section{Cell survival assay}

Neuronal viability was detected by using a 2-(2-methoxy-4-nitrophenyl)-3-(4-nitrophenyl)-5-(2,4-disulfophenyl)-2H-tetrazolium monosodium salt (WST-8) assay (Dojindo Molecular Technologies, Gaithersburg, ML, USA). The cell survival rate was expressed as the viability percentage of the vehicle-treated cells.

\section{Caspase-9, caspase- 8 and caspase- 3 activities}

The caspase- 9 , caspase- 8 and caspase- 3 activities in cell lysates were determined using caspase- 9 , caspase- 8 and caspase-3 Colormetric Assay Kits (Chemicon, Rosemont, IL). Approximately $50 \mu \mathrm{g}$ of protein was incubated with DEVD-pNA (for caspase-3; $50 \mu \mathrm{M}$ ), IETD-pNA (for caspase-8; $50 \mu \mathrm{M}$ ) or LEHD-pNA (for caspase-9; $50 \mu \mathrm{M}$ ) and $10 \mathrm{mM} \mathrm{DTT}$ at $37^{\circ} \mathrm{C}$ for $2 \mathrm{~h}$. Substrate hydrolysis was determined as absorbance change at $405 \mathrm{~nm}$ in a microplate reader. Enzymatic activity was expressed in arbitrary units (optical density, OD) per mg protein.

\section{Western blot analysis}

Whole cellular extracts and nuclear protein fractions were prepared and protein concentration was determined by using Bradford protein assay (Bio-Rad, Hercules, CA, USA); 10-50 $\mu \mathrm{g}$ of protein was analyzed by $10 \%$ SDS-PAGE and transferred to nitrocellulose membranes that were then blocked with $5 \%$ nonfat milk in TBS (100 mM, Tris pH 8.0, $1.5 \mathrm{M}$ of $\mathrm{NaCl}, 0.1 \%$ Tween 20) for $1 \mathrm{~h}$. The membranes were incubated overnight with primary antibodies, washed with TBS, and incubated with a horseradish peroxidase-conjugated secondary antibody for $1 \mathrm{~h}$. Immunoreactivity was detected by using the ECL detection system (Thermo Scientific, Rockford, IL, USA).

\section{Akt kinase assay}

We followed instructions in the Akt kinase assay kit from Cell Signaling Technology (catalog \# 9840). Cells were washed with PBS and lysed in cell lysis buffer. Twenty microliters of immobilized Akt primary antibody bead slurry was added to $200 \mu \mathrm{l}$ of whole-cell extract (150 $\mu$ g of protein) overnight at $4^{\circ} \mathrm{C}$. After centrifugation, the supernatant was saved for $\beta$-actin detection by western blot to confirm that the same amount of wholecell extract was used for the Akt kinase assay as reported [41]. Immunoprecipitates were washed three times with lysis buffer and twice with Akt kinase buffer. Kinase assays were performed for $30 \mathrm{~min}$ at $30^{\circ} \mathrm{C}$ under continuous agitation in kinase buffer containing $200 \mu \mathrm{M}$ ATP, $1 \mu \mathrm{g}$ of GSK-3 fusion protein. Samples were analyzed by western blot using phospho-GSK-3 $\alpha / \beta$ (Ser21/9) antibody.

\section{Ad. ${ }^{\text {AktK179A }}$ and Ad.FKHRL-TM constructs}

The kinase-inactive $A k t^{\mathrm{K} 179 \mathrm{~A}}$ [46] or a triple mutant of FKHRL1 (FKHRL1-TM) [47] was cloned into a GFP-containing adenoviral vector using AdEasy TMXL system (Stratagene, Cedar Creek, TX, USA). The adenoviral product containing $\mathrm{Akt}^{\mathrm{K} 179 \mathrm{~A}}$ or FKHRL1-TM was amplified in HEK 293A cells from American Type Culture Collection (ATCC, Manassas, VA, USA) and purified using ViraKit TM(Virapur, San Diego, CA, USA). Cortical neurons were transduced with adenoviral constructs (200 MOI) $24 \mathrm{~h}$ before studies. The transduction efficiency was determined by GFP signal and western blot analysis.

\section{Tyro3 tyrosine phosphorylation}

Neurons were lysed with Radio ImmunoPreciptation Assay (RIPA) Buffer (50 mM Tris, pH 8.0, $150 \mathrm{mM}$ $\mathrm{NaCI}, 0.1 \%$ SDS, $1.0 \%$ NP-40, 0.5\% sodium deoxycholate and Roche protease inhibitor cocktail) and incubated with a rabbit anti-phospho-tyrosine antibody (Abcam, Cambridge, MA) or a control non-immune 
IgG (Sigma-Aldrich) overnight at $4^{\circ} \mathrm{C}$. The samples were then immunoprecipitated using a protein G immunoprecipitation kit (Roche) followed by SDS-PAGE separation and transfer onto nitrocellulose membranes (Millipore Corp). After blocking non-specific sites with $5 \%$ milk, the membranes were incubated with a rat monoclonal anti-mouse Tyro3 antibody (R\&D Systems) or a rabbit anti-mouse vascular endothelial growth factor receptor 2 (VEGFR2) antibody (Millipore, Billerica, $\mathrm{MA}$ ) for a loading control. Following incubation with an HRP-conjugated donkey-anti goat secondary antibody (Santa Cruz Biotechnology), the immunoreactivity was detected using the SuperSignal ${ }^{\circledR}$ West Pico chemiluminescent substrate (Thermo Scientific). Cells were treated with mouse PS for $2 \mathrm{~h}$.

\section{Statistical analysis}

We used S-plus 7.0 for statistical calculations. Data are presented as mean \pm SEM. Student's $t$-test and one-way analysis of variance (ANOVA) followed by Tukey's posthot test were used to determine statistically significant differences. $P<0.05$ was considered statistically significant.

\section{Abbreviations \\ PS: Protein S; NMDA: N-methyl-D-aspartate; NMDAR: N-methyl-D-aspartate receptor; TAM: Tyro3, Axl, Mer; tPA: tissue plasminogen activator; FasL: Fas- ligand; BBB: blood-brain barrier; PI3K: phosphatidylinositol 3-kinase; GSK3: glycogen synthase kinase 3.}

\section{Acknowledgements}

This work was supported by the National Institutes of Health grant HL63290 and HL081528 to BVZ and HL104074 to JHG. We thank Dr. G. Lemke (Salk Institute, La Jolla, U.S.A.) for providing Tyro3, Axl and Mer transgenic mice.

\section{Author details}

${ }^{1}$ Center for Neurodegenerative and Vascular Brain Disorders, Department of Neurosurgery and Neurology, University of Rochester Medical Center, Rochester, NY 14642, USA. ${ }^{2}$ Department of Molecular and Experimental Medicine, The Scripps Research Institute, La Jolla, CA 92037, USA. ${ }^{3}$ Department of Pharmacology and Physiology, University of Rochester Medical Center, Rochester, NY 14642, USA.

\section{Authors' contributions}

HG supervised most of the experiments, performed data analysis and helped with the manuscript preparation. TMB carried out most of the experiments. ZZ performed the Tyro3 tyrosine phosphorylation assay and carried out studies with the adenoviral contstructs. JAF provided and characterized mouse recombinant PS. JHG contributed to study design working with BVZ. RSF provided $A d^{A k K K 179 A}$ and Ad.FKHRL-TM constructs and provided critical comments to the manuscript. BVZ designed the entire study, supervised all portions of the study, and wrote the manuscript. All authors read and approved the final manuscript.

\section{Competing interests}

The authors declare that they have no competing interests.

Received: 7 December 2010 Accepted: 3 February 2011 Published: 3 February 2011

\section{References}

1. The National Institute of Neurological Disorders and Stroke rt-PA Stroke Study Group: Tissue plasminogen activator for acute ischemic stroke. N Engl J Med 1995, 333:1581-1587.
2. Kleindorfer D, Lindsell CJ, Brass L, Koroshetz W, Broderick JP: National US estimates of recombinant tissue plasminogen activator use: ICD-9 codes substantially underestimate. Stroke 2008, 39:924-928.

3. Carpenter CR, Keim SM, Milne WK, Meurer WJ, Barsan WG: Thrombolytic Therapy for Acute Ischemic Stroke beyond Three Hours. J Emerg Med 2010, 40:82-92.

4. Yepes M, Sandkvist M, Moore EG, Bugge TH, Strickland DK, Lawrence DA: Tissue-type plasminogen activator induces opening of the blood-brain barrier via the LDL receptor-related protein. J Clin Invest 2003, 112:1533-1540

5. Cheng T, Petraglia AL, Li Z, Thiyagarajan M, Zhong Z, Wu Z, Liu D, Maggirwar SB, Deane R, Fernandez JA, LaRue B, Griffin JH, Chopp M, Zlokovic BV: Activated protein C inhibits tissue plasminogen activatorinduced brain hemorrhage. Nat Med 2006, 12:1278-1285.

6. Yepes M, Roussel BD, Ali C, Vivien D: Tissue-type plasminogen activator in the ischemic brain: more than a thrombolytic. Trends Neurosci 2009, 32:48-55.

7. Zhang L, Zhang ZG, Zhang C, Zhang RL, Chopp M: Intravenous administration of a GPIIb/llla receptor antagonist extends the therapeutic window of intra-arterial tenecteplase-tissue plasminogen activator in a rat stroke model. Stroke 2004, 35:2890-2895.

8. Ding G, Jiang $Q$, Zhang L, Zhang ZG, Li L, Knight RA, Ewing JR, Wang Y, Chopp M: Analysis of combined treatment of embolic stroke in rat with r-tPA and a GPIllb/llla inhibitor. J Cereb Blood Flow Metab 2005, 25:87-97.

9. Marder VJ, Jahan R, Gruber T, Goyal A, Arora V: Thrombolysis with plasmin: implications for stroke treatment. Stroke 2010, 41:S45-49.

10. The National Institute of Neurological Disorders and Stroke rt-PA Stroke Study Group: Intracerebral hemorrhage after intravenous t-PA therapy for ischemic stroke. Stroke 1997, 28:2109-2118.

11. Saver JL, Levine SR: Alteplase for ischaemic stroke-much sooner is much better. Lancet 2010, 375:1667-1668.

12. Wang YF, Tsirka SE, Strickland S, Stieg PE, Soriano SG, Lipton SA: Tissue plasminogen activator (TPA) increases neuronal damage after focal cerebral ischemia in wild-type and tPA-deficient mice. Nat Med 1998, 4:228-231

13. Nagai N, Vanlinthout I, Collen D: Comparative effects of tissue plasminogen activator, streptokinase, and staphylokinase on cerebral ischemic infarction and pulmonary clot lysis in hamster models. Circulation 1999, 100:2541-2546.

14. Liu D, Cheng T, Guo H, Fernandez JA, Griffin JH, Song X, Zlokovic BV: Tissue plasminogen activator neurovascular toxicity is controlled by activated protein C. Nat Med 2004, 10:1379-1383.

15. Nicole O, Docagne F, Ali C, Margaill I, Carmeliet P, MacKenzie ET, Vivien D, Buisson A: The proteolytic activity of tissue-plasminogen activator enhances NMDA receptor-mediated signaling. Nat Med 2001, 7:59-64.

16. Baron A, Montagne A, Casse F, Launay S, Maubert E, Ali C, Vivien D: NR2Dcontaining NMDA receptors mediate tissue plasminogen activatorpromoted neuronal excitotoxicity. Cell Death Differ 2009, 17:860-71.

17. Benchenane K, Castel H, Boulouard M, Bluthe R, Fernandez-Monreal M, Roussel BD, Lopez-Atalaya JP, Butt-Gueulle S, Agin V, Maubert E, Dantzer R, Touzani O, Dauphin F, Vivien D, Ali C: Anti-NR1 N-terminaldomain vaccination unmasks the crucial action of tPA on NMDAreceptor-mediated toxicity and spatial memory. J Cell Sci 2007, 120:578-585.

18. Matys $\mathrm{T}$, Strickland $\mathrm{S}$ : Tissue plasminogen activator and NMDA receptor cleavage. Nat Med 2003, 9:371-372, author reply 372-373.

19. Arundine M, Tymianski M: Molecular mechanisms of glutamatedependent neurodegeneration in ischemia and traumatic brain injury. Cell Mol Life Sci 2004, 61:657-668.

20. Lau A, Tymianski M: Glutamate receptors, neurotoxicity and neurodegeneration. Pflugers Arch 2010, 460:525-542.

21. Dahlback B: The tale of protein $\mathrm{S}$ and $\mathrm{C} 4 \mathrm{~b}$-binding protein, a story of affection. Thromb Haemost 2007, 98:90-96.

22. Benzakour O, Formstone C, Rahman S, Kanthou C, Dennehy U, Scully MF, Kakkar W, Cooper DN: Evidence for a protein S receptor(s) on human vascular smooth muscle cells. Analysis of the binding characteristics and mitogenic properties of protein $\mathrm{S}$ on human vascular smooth muscle cells. Biochem J 1995, 308(Pt 2):481-485.

23. Fernandez JA, Heeb MJ, Xu X, Singh I, Zlokovic BV, Griffin JH: Speciesspecific anticoagulant and mitogenic activities of murine protein S. Haematologica 2009, 94:1721-1731. 
24. Gasic GP, Arenas CP, Gasic TB, Gasic GJ: Coagulation factors X, Xa, and protein $S$ as potent mitogens of cultured aortic smooth muscle cells. Proc Natl Acad Sci USA 1992, 89:2317-2320.

25. Liu D, Guo H, Griffin JH, Fernandez JA, Zlokovic BV: Protein S confers neuronal protection during ischemic/hypoxic injury in mice. Circulation 2003, 107:1791-1796.

26. Zhu D, Wang Y, Singh I, Bell RD, Deane R, Zhong Z, Sagare A, Winkler EA, Zlokovic BV: Protein S controls hypoxic/ischemic blood-brain barrier disruption through the TAM receptor Tyro3 and sphingosine 1phosphate receptor. Blood 2010, 115:4963-4972.

27. Zhong Z, Wang Y, Guo H, Sagare A, Bell RD, Fernandez JA, Barrett TM, Griffin JD, Freeman RS, Zlokovic BV: Protein S protects neurons from excitotoxic injury by activating the TAM receptor Tyro-PI3K-Akt pathway through its SHBG-like region. J Neurosci 2010, 30:15521-15534.

28. del Peso L, Gonzalez-Garcia M, Page C, Herrera R, Nunez G: Interleukin-3induced phosphorylation of BAD through the protein kinase Akt. Science 1997, 278:687-689.

29. Datta SR, Dudek H, Tao X, Masters S, Fu H, Gotoh Y, Greenberg ME: Akt phosphorylation of BAD couples survival signals to the cell-intrinsic death machinery. Cell 1997, 91:231-241.

30. Mayo LD, Donner DB: A phosphatidylinositol 3-kinase/Akt pathway promotes translocation of Mdm2 from the cytoplasm to the nucleus. Proc Natl Acad Sci USA 2001, 98:11598-11603.

31. Gottlieb TM, Leal JF, Seger R, Taya Y, Oren M: Cross-talk between Akt, p53 and Mdm2: possible implications for the regulation of apoptosis. Oncogene 2002, 21:1299-1303.

32. Prieto $A L$, Weber $J$, Lai $C$ : Expression of the receptor protein-tyrosine kinases Tyro-3, Axl, and mer in the developing rat central nervous system. J Comp Neurol 2000, 425:295-314.

33. Hall MO, Obin MS, Heeb MJ, Burgess BL, Abrams TA: Both protein S and Gas6 stimulate outer segment phagocytosis by cultured rat retinal pigment epithelial cells. Exp Eye Res 2005, 81:581-591.

34. Uehara $\mathrm{H}$, Shacter $\mathrm{E}$ : Auto-oxidation and oligomerization of protein $\mathrm{S}$ on the apoptotic cell surface is required for Mer tyrosine kinase-mediated phagocytosis of apoptotic cells. J Immunol 2008, 180:2522-2530.

35. Prasad D, Rothlin CV, Burrola P, Burstyn-Cohen T, Lu Q, Garcia de Frutos P, Lemke G: TAM receptor function in the retinal pigment epithelium. $\mathrm{Mol}$ Cell Neurosci 2006, 33:96-108

36. Lu Q, Lemke $\mathrm{G}$ : Homeostatic regulation of the immune system by receptor tyrosine kinases of the Tyro 3 family. Science 2001, 293:306-311.

37. Burstyn-Cohen T, Heeb MJ, Lemke G: Lack of protein $\mathrm{S}$ in mice causes embryonic lethal coagulopathy and vascular dysgenesis. J Clin Invest 2009, 119:2942-2953.

38. Saller F, Brisset AC, Tchaikovski SN, Azevedo M, Chrast R, Fernandez JA, Schapira M, Hackeng TM, Griffin JH, Angelillo-Scherrer A: Generation and phenotypic analysis of protein S-deficient mice. Blood 2009, 114:2307-2314

39. Hsieh CC, Kuo YH, Kuo CC, Chen LT, Cheung CH, Chao TY, Lin CH, Pan WY, Chang CY, Chien SC, Chen TW, Lung CC, Chang JY: Chamaecypanone C, a novel skeleton microtubule inhibitor, with anticancer activity by trigger caspase 8-Fas/FasL dependent apoptotic pathway in human cancer cells. Biochem Pharmacol 2010, 79:1261-1271.

40. Shioda N, Ishigami T, Han F, Moriguchi S, Shibuya M, Iwabuchi Y, Fukunaga K: Activation of phosphatidylinositol 3-kinase/protein kinase B pathway by a vanadyl compound mediates its neuroprotective effect in mouse brain ischemia. Neuroscience 2007, 148:221-229.

41. Zhao H, Shimohata T, Wang JQ, Sun G, Schaal DW, Sapolsky RM, Steinberg GK: Akt contributes to neuroprotection by hypothermia against cerebral ischemia in rats. J Neurosci 2005, 25:9794-9806.

42. Brunet A, Bonni A, Zigmond MJ, Lin MZ, Juo P, Hu LS, Anderson MJ, Arden KC, Blenis J, Greenberg ME: Akt promotes cell survival by phosphorylating and inhibiting a Forkhead transcription factor. Cell 1999, 96:857-868.

43. Accili D, Arden KC: FoxOs at the crossroads of cellular metabolism, differentiation, and transformation. Cell 2004, 117:421-426.

44. Birkenkamp KU, Coffer PJ: FOXO transcription factors as regulators of immune homeostasis: molecules to die for? J Immunol 2003, $171: 1623-1629$.
45. Kops GJ, de Ruiter ND, De Vries-Smits AM, Powell DR, Bos JL, Burgering BM: Direct control of the Forkhead transcription factor AFX by protein kinase B. Nature 1999, 398:630-634.

46. Crowder RJ, Freeman RS: Phosphatidylinositol 3-kinase and Akt protein kinase are necessary and sufficient for the survival of nerve growth factor-dependent sympathetic neurons. J Neurosci 1998, 18:2933-2943.

47. Gomez-Gutierrez JG, Souza V, Hao HY, Montes de Oca-Luna R, Dong YB, Zhou HS, McMasters KM: Adenovirus-mediated gene transfer of FKHRL1 triple mutant efficiently induces apoptosis in melanoma cells. Cancer Biol Ther 2006, 5:875-883.

48. Kikuchi S, Nagai T, Kunitama M, Kirito K, Ozawa K, Komatsu N: Active FKHRL1 overcomes imatinib resistance in chronic myelogenous leukemia-derived cell lines via the production of tumor necrosis factorrelated apoptosis-inducing ligand. Cancer Sci 2007, 98:1949-1958.

49. Guo H, Liu D, Gelbard H, Cheng T, Insalaco R, Fernandez JA, Griffin JH, Zlokovic BV: Activated protein C prevents neuronal apoptosis via protease activated receptors 1 and 3. Neuron 2004, 41:563-572.

50. Plesnila N, Zinkel S, Le DA, Amin-Hanjani S, Wu Y, Qiu J, Chiarugi A, Thomas SS, Kohane DS, Korsmeyer SJ, Moskowitz MA: BID mediates neuronal cell death after oxygen/glucose deprivation and focal cerebral ischemia. Proc Natl Acad Sci USA 2001, 98:15318-15323.

51. Zhang Z, Zhang L, Yepes M, Jiang Q, Li Q, Arniego P, Coleman TA, Lawrence DA, Chopp M: Adjuvant treatment with neuroserpin increases the therapeutic window for tissue-type plasminogen activator administration in a rat model of embolic stroke. Circulation 2002, 106:740-745.

52. Lopez-Atalaya JP, Roussel BD, Levrat D, Parcq J, Nicole O, Hommet Y, Benchenane K, Castel H, Leprince J, To Van D, Bureau R, Rault S, Vaudry H, Petersen KU, Santos JS, Ali C, Vivien D: Toward safer thrombolytic agents in stroke: molecular requirements for NMDA receptor-mediated neurotoxicity. J Cereb Blood Flow Metab 2008, 28:1212-1221.

53. Pawlak R, Melchor JP, Matys T, Skrzypiec AE, Strickland S: Ethanolwithdrawal seizures are controlled by tissue plasminogen activator via modulation of NR2B-containing NMDA receptors. Proc Natl Acad Sci USA 2005, 102:443-448

54. Martin AM, Kuhlmann C, Trossbach S, Jaeger S, Waldron E, Roebroek A, Luhmann HJ, Laatsch A, Weggen S, Lessmann V, Pietrzik CU: The functional role of the second NPXY motif of the LRP1 beta-chain in tissue-type plasminogen activator-mediated activation of $\mathrm{N}$-methyl-D-aspartate receptors. J Biol Chem 2008, 283:12004-12013.

55. Wang X, Lee SR, Arai K, Tsuji K, Rebeck GW, Lo EH: Lipoprotein receptormediated induction of matrix metalloproteinase by tissue plasminogen activator. Nat Med 2003, 9:1313-1317.

56. Polavarapu R, Gongora MC, Yi H, Ranganthan S, Lawrence DA, Strickland D, Yepes M: Tissue-type plasminogen activator-mediated shedding of astrocytic low-density lipoprotein receptor-related protein increases the permeability of the neurovascular unit. Blood 2007, 109:3270-3278.

57. Zlokovic BV: Neurodegeneration and the neurovascular unit. Nat Med 2010, 16:1370-1371.

58. Bell RD, Winkler EA, Sagare AP, Singh I, LaRue B, Deane R, Zlokovic BV: Pericytes control key neurovascular functions and neuronal phenotype in the adult brain and during brain aging. Neuron 2010, 68:409-427.

59. Winkler EA, Bell RD, Zlokovic BV: Pericyte-specific expression of PDGF beta receptor in mouse models with normal and deficient PDGF beta receptor signaling. Mol Neurodegener 2010, 5:32.

60. Gobel K, Melzer N, Herrmann AM, Schuhmann MK, Bittner S, Ip CW, Hunig T, Meuth SG, Wiendl H: Collateral neuronal apoptosis in CNS gray matter during an oligodendrocyte-directed CD8(+) T cell attack. Glia 2010, 58:469-480.

61. Justo P, Lorz C, Sanz A, Egido J, Ortiz A: Intracellular mechanisms of cyclosporin A-induced tubular cell apoptosis. J Am Soc Nephrol 2003, 14:3072-3080

62. Lu Q, Gore M, Zhang Q, Camenisch T, Boast S, Casagranda F, Lai C, Skinner MK, Klein R, Matsushima GK, Earp HS, Goff SP, Lemke G: Tyro-3 family receptors are essential regulators of mammalian spermatogenesis. Nature 1999, 398:723-728

63. Rothlin CV, Ghosh S, Zuniga El, Oldstone MB, Lemke G: TAM receptors are pleiotropic inhibitors of the innate immune response. Cell 2007, 131:1124-1136. 
64. Brewer GJ, Torricelli JR, Evege EK, Price PJ: Optimized survival of hippocampal neurons in B27-supplemented Neurobasal, a new serumfree medium combination. J Neurosci Res 1993, 35:567-576.

65. Guo H, Singh I, Wang Y, Deane R, Barrett T, Fernandez JA, Chow N, Griffin JH, Zlokovic BV: Neuroprotective activities of activated protein C mutant with reduced anticoagulant activity. Eur J Neurosci 2009, 29:1119-1130

doi:10.1186/1750-1326-6-13

Cite this article as: Guo et al:: Protein S blocks the extrinsic apoptotic cascade in tissue plasminogen activator/N-methyl D-aspartate-treated neurons via Tyro3-Akt-FKHRL1 signaling pathway. Molecular

Neurodegeneration 2011 6:13.

Submit your next manuscript to BioMed Central and take full advantage of:

- Convenient online submission

- Thorough peer review

- No space constraints or color figure charges

- Immediate publication on acceptance

- Inclusion in PubMed, CAS, Scopus and Google Scholar

- Research which is freely available for redistribution

Submit your manuscript at www.biomedcentral.com/submit
() Biomed Central 